\title{
DEVELOPMENT OF FRAMEWORK FOR HIGH SCHOOL GEOGRAPHY CURRICULUM BASED ON ISLAMIC VALUES
}

\author{
Aniq Darajat ${ }^{1}$, Ulil Amri Syafri ${ }^{2}$, Ibdalsyah ${ }^{3}$ \\ ${ }^{1}$ Student of Graduate School, Universitas Ibn Khaldun, Bogor \\ ${ }^{2,3}$ Graduate School, Universitas Ibn Khaldun, Bogor \\ e-mail: aniq.darajat@gmail.com \\ e-mail: ulamris@gmail.com \\ email: ibdalsyah@fai.uika-bogor.ac.id
}

\section{Received: 30/07/2020, Accepted: 25/08/2020, Published: 29/08/2020}

\begin{abstract}
Throughout history, Geography has a special position in the life of a Muslim, so they feel the need to learn this knowledge, more than any other discipline. Unfortunately, Geography learning, especially in high schools ignoring these facts and then empty of its association with Islamic values. This paper seeks to formulate the initial steps to develop a high school Geography curriculum based on Islamic values. This research uses a library research approach. The steps taken in this study includes study of key concepts in Islamic education that can be used as an educational curriculum framework that is inline with Islamic values. Principles for the compilation of Islamic values based churriculum, among others. First, the objectives are aligned and are a translation of the objectives of Islamic education. Second, the content of the material includes and corresponds to Islamic educational material including the history of Geography, great cotibution of Muslim scholars, and geographical conditions of Muslim countries. It also should be free from material content that are not aligned with Islamic values. Third, the teaching method the teaching of science can no longer be separated from the teaching of revelation (al-Qur'an and as-Sunnah). It also provides learning experiences appropriate for moral and spiritual development by providing a balance between a student-centered and a subject-centered approach. Fourth, evaluation of education needs to pay attention to the achievement of the objectives of Islamic education, and not limited to aspects of knowledge, attitudes and skills but is empty of the achievement of ultimate educational goals.
\end{abstract}

Keywords: Framework, Geography, High School, Curriculum, Islamic Values

\begin{abstract}
ABSTRAK
Dalam sejarah peradaban Islam, Ilmu Geografi memiliki kedudukan spesial dalam kehidupan seorang Muslim, sehingga mereka merasa perlu mempelajari pengetahuan ini, lebih dari disiplin ilmu lainnya. Sayangnya, pembelajaran Geografi, terutama di sekolah menengah mengabaikan fakta-fakta ini dan kemudian kosong dari nilai-nilai Islam. Makalah ini berupaya merumuskan langkah-langkah awal untuk mengembangkan kurikulum Geografi SMA berdasarkan nilai-nilai Islam. Penelitian ini menggunakan pendekatan penelitian kepustakaan. Langkah-langkah yang diambil dalam penelitian ini adalah mengkaji konsep-konsep kunci dalam pendidikan Islam yang dapat digunakan sebagai kerangka kurikulum pendidikan yang sejalan dengan nilai-nilai Islam. Prinsip-prinsip untuk penyusunan kurikulum berdasarkan nilai-nilai Islam, antara lain. Pertama, tujuannya selaras dan merupakan turunan dari tujuan pendidikan Islam. Kedua, materi mencakup dan sesuai dengan materi pendidikan Islam termasuk sejarah perkembangan Geografi, peran besar cendekiawan Muslim, dan kondisi geografis negara-negara Muslim. Konten juga harus bebas dari materi yang tidak selaras dengan nilainilai Islam. Ketiga, metode pengajaran pengajaran sains tidak bisa lagi dipisahkan dari pengajaran wahyu (al-Qur'an dan as-Sunnah), juga memberikan pengalaman belajar yang sesuai untuk perkembangan moral dan spiritual dengan memberikan keseimbangan antara pendekatan yang berpusat pada siswa dan pendekatan yang berpusat pada subjek. Keempat, evaluasi pendidikan perlu
\end{abstract}


memperhatikan pencapaian tujuan pendidikan Islam, dan tidak terbatas pada aspek pengetahuan, sikap dan keterampilan tetapi kosong dari pencapaian tujuan pendidikan yang hakiki.

Kata kunci: Kerangka kerja, Geografi, Kurikulum SMA, Nilai-nilai Islam

\section{A. INTRODUCTION}

Science taught today as a national curriculum demands knowledge that departs from the Western way of life, which cannot be separated from the values, mindset that exist in Western civilization. This is a big challenge for Islamic educational institutions, which try to instill an Islamic way of life in their students, but are 'forced' to teach knowledge that is built from a materialist and secular Western worldview.

In the case of Muslims, there is not even a theoretical framework for the teaching of science from an Islamic perspective. During the last fifty years, some Muslim scholars have produced a powerful critique of modern science, but little attention has been paid to alternative ways of doing science on the ground, and even less has been said about teaching science from an Islamic perspective.

In the social sciences and humanities at the Senior High School level, this challenge is even greater. Where the conflicting aspects between the Western way of life and the Islamic way of life in this family are more clearly seen. The social, economic, and cultural order in the Western concept is certainly very different from the Islamic concept, unfortunately, this secular Western version of Social Sciences must be taught to students in Islamic schools.

Islamic educational institutions are faced with a tough task, namely conducting indepth studies of the national curriculum, identifying elements that are contrary to the Islamic way of life, then undertaking follow-up efforts to anticipate the curriculum in the form of developments and further studies towards curriculum Islamization efforts.

This paper seeks to formulate the initial steps to develop a High School Geography Science curriculum that is based on Islamic values, in the form of the principles and stages of the Islamic Geography curriculum based on Islamic values

\section{B. LITERATURE REVIEWS}

The concept of science in Islam is, in fact, different from the concept of science understood by the West, which currently dominates the understanding of science in modern society. From the results of tracking the definition of science in the Webster's New World Dictionary, Kartanegara (2003) 
in Handrianto (2016) concluded that in the Western world itself, the definition of science has experienced a shift. From the original meaning only "knowledge", turned into "systematic knowledge based on sensory observation". This trend then leads to the limitation of the scientific environment only to the physical world. This can be seen from the definition given by the dictionary of the word science as "systematic knowledge of nature and the physical world" (Handrianto 2016)

Islam has a unique perspective on science, which is not possessed by other ideologies or civilizations. This particular perspective then gives birth to a philosophical, methodological, and implementative basis for all scientific and technological activities, which in turn will give birth to what is referred to as "Islamic Science". The process, efforts, and steps taken to realize Islamic science are termed the "Islamization of Science"

al-Najjar (1982) states that the scientific writings published in the last two centuries were mostly written in mere materialistic background. As a result, the existing sciences, many gave birth to the wrong conclusions, as an implication of the materialistic philosophy that is the basis, rejecting religion and its basic values (faith), as well as the moral and ethical ties that originate from that religion.(Al-Najjar 1982)

\section{RESEARCH METHOD}

This research uses a library research approach. Library research is research conducted by reading books or magazines and other data sources in libraries. This research activity was carried out by collecting data from various literatures, both in the library and in other places. The literature used is not limited to books, but can also be in the form of documentation materials, magazines, newspapers, and others.(Mahmud 2011)

This research also uses content analysis or document research. Content analysis or document analysis (content or document analysis) is intended to collect and analyze official documents, documents whose validity and validity are guaranteed, both legislative and policy documents as well as research results. The analysis activity is intended to find out the meaning, position, and relationship between various concepts, policies, programs, activities, events that occur, to further determine the benefits, results, or the impact of these things. (Sukmadinata 2006)

The steps taken in this study are to examine key concepts in Islamic education that can be used as an educational curriculum 
framework that is inline with Islamic values. Then, specifically, it examines the philosophical and historical aspects in the discipline of Geography which are closely related to the values of Islamic education in order to obtain fundamental things in the discipline of Geography such as learning objectives, objects studied, and the development of scientific methods in studying Geography. Furthermore, this research analyse the high school Geography curriculum currently applied by the government in terms of the principles of Islamic education.

\section{RESULT AND DISCUSSION}

\section{Developing Framework For Islamic Based Geography Curriculum}

The position of the curriculum is very important in the discipline of education. Curriculum is considered as the queen in the discipline, as is Physics in the natural sciences. Curriculum can be defined as designing learning experiences even though discussion of the definition will be broader and complex. The design of education is guided by the philosophy, beliefs and background of a country. A good curriculum will produce the desired goals even though it may be failed. Improvement of education that does not involve curriculum aspects is considered as patchy change.

\section{Principles of Islamic Based Curriculum Development}

Hashim (1998) in Nawi (2012) describes several steps that need to be taken to implement the curriculum Islamization process as follows: (Nawi 2012)

1. The formulation of an educational philosophy should be based on Islamic worldview.

2. Ensure that all sources for determining educational goals come from Islamic worldview.

3. Islamic education curriculum must maintain the hierarchy of science in Islam specifically the fardhu ain and fardhu kifayah.

4. Introducing an integrated education system in which both naqliah and aqliah science are taught and given equal opportunities for specialization based on students' abilities and interests.

5. Integrate the formal curriculum, based on Islamic worldview which develops the principle of Tawheed.

6. Providing learning experiences that are appropriate especially for moral and spiritual development by providing a balance between a student-centered approach and a subject-centered approach. 
7. Establish an evaluation system that is in line with Islamic educational goals.

\section{Four Aspects of Curriculum}

Citing Ralph W. Tyler, Ahmad Tafsir

explained that the curriculum was

structured to answer four fundamental

questions: (Tafsir 2013)

1. What is the purpose of teaching?

2. What learning experiences are prepared to achieve the goal?

3. How is the learning experience carried out?

4. How to determine that the goal has been achieved?

In other words, the curriculum consists of four components:

1. Purpose

2. Content or program

3. The method or process of teaching and learning

4. Evaluation

The Islamization of the curriculum also means the application of Islamic values in the curriculum, so it must cover these four aspects. (Langgulung 2001)

Practically it can be concluded that in order to Islamize the curriculum, four aspects of the curriculum must be formulated in accordance with Islamic principles and values. First, the objectives are aligned and are a translation of the objectives of Islamic education. This goal becomes a reference for all components that follow. This means, the learning objectives in each subject should contain and reduce in more detail the main objectives of Islamic education.

\section{a. First Aspects: The Purpose of Geography Curriculum}

Geography as a science has developed in the Islamic civilization as a systematic study. As Islamic sciences developed in Islam as a systematic and methodological study, based on Al qur'an, sunnah and shariah, the Muslim scholars with scientific mind developed the science of geography. When Muslim scholars developed the science of geography, geography in turn influenced every sphere of the Muslims life. Geography and astronomical aspects play an important role in muslims religious rituals and practices. The religious moment is framed according to the movement of the moon, so Muslims follow the lunar calendar. All their holidays, festivals and important events take place according to the lunar calendar. (Svd 2010)

\section{The Position of Geography in Islamic} Science 
The author tries to trace the position of Geography in the treasures of Islamic religious heritage. Shidiq Hasan Khan alQannujy in his book which explains the ins and outs of various scientific disciplines entitled Abjad al-'Ulum, explains that Geography comes from Greek which means the picture of the earth. Al-Qannujy (1978) also mentions the definition written by Daud al-Anthaqy (died 1008 H / 1599 AD) in his book: "Tadzkiratu Uli al-Albab wa alJami 'li al-' Ajab al-Ujab" that Geography is science that discusses the state of the earth, in terms of the division of regions / climate, mountains, rivers and differences in the conditions of its population. (Al-Qannujy 1978)

Abu Bakar Jabir al-Jazairy grouped Geography into a definite science group (alRiyadhiyyat), and stated that the law of studying this science was permissible, it could even be farhdhu kifayah or fardhu 'ain in certain conditions.(Al-Jazairy 2001)

\section{Scientists Intense of Studying Geography Because of The Encouragement of Faith}

The enormous contribution of Muslim scientists in the field of Geography is motivated by several factors: First, the impetus of Allah's repeated commands in several places in the Qur'an so that Muslims travel on earth, paying attention to the condition of the earth and its contents. Among these are the words of Allah in Surat al-An'am verse 11:

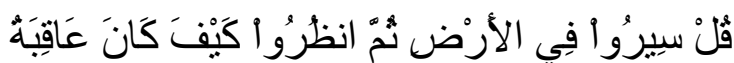

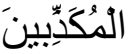

Say: "Walk on the face of the earth, then pay attention to the end of those who reject it" (QS. Al An'am: 11)

In addition to the verse, there are also many commands and cues that humans pay attention to the state of the earth and its contents to take lessons. This is what is believed to be the motivation of Muslim scientists during the light to carry out immoral activities in the field of Geography.(Salim 1999)

Second, Muslims (Arabs) are encouraged to study Geography because of the natural surroundings. It is impossible for them to carry out trading, preaching or military activities in a vast desert without knowing the position of the stars and mountains around them.(Nordin 2000)

Thus a little picture of the position of Geography in Islamic civilization. This shows that Geography has a special position in the life of a Muslim. So they feel the need to learn this knowledge, more than any other discipline. Muslims have many purposes and reason to study Geography. 
Unfortunately, the practices in Islamic schools ignoring these facts and then completely empty of its association with Islamic values.

\section{b. Second Aspect: The Contents of Geography Curriculum}

The content includes and corresponds to Islamic educational material and is free from material content that conflicts with Islamic values. Educational material should refer to educational goals and not vice versa (Abdurrahmansyah 2002). Supraha (2017) revealed that one important element in science education material in an Islamic perspective is incorporating the history of science material. According to Supraha, the change in the content of the teaching material so as to contain the facts of the history of science as a whole is the main basis of the most basic applied applications. (Supraha 2017)

Further implementation of the Islamization of the content of the science education curriculum, according to Supraha (2017), can also be done by developing seven concepts of Islamization of science which are refinements of seven similar concepts proposed by Zarman (2012). The seven concepts of Islamization of science in the curriculum are:
1. Provide an introduction containing Islamic advice.

2. Insert the expression of God's omnipotence.

3. Reveal the wisdom of natural creation that fosters gratitude.

4. Entering the Qur'anic verses or relevant hadiths.

5. Correcting scientific concepts that are contrary to Islamic teachings.

6. Incorporating teaching of science history into science learning materials.

7. Linking science material with the application of Islamic teachings. (Supraha 2017)

Some crucial aspects that need to be included in the contents of the Geography curriculum include:

\section{The History of Geography and the} Great Contribution of Muslim scholars

Geography is a discipline that has long roots in the history of Islamic civilization. Islamic scientists have shown very high achievements in Geography, appearing to be qualified researchers and experts who are recognized for their expertise in the field. To mention a few of them, such as Ya'qut al-Hamawi, al-Biruni, Ibn Khaldun, alIdrisi, Ibn Majid, and others. Von Kremer, 
an Austrian Orientalist stated about the expertise and scientific ethos of a Muslim geographer, Ya'qut al-Hamawi:

I know nothing that brings and home to use the picture of Muslim Zeal for truth more clearly and emphatically than an account of the travels of the great Arab geographer: Ya'qut al-Hamawi (Bukhsh 1905, 11, 47)

George Sarton, the pioneer of the history of science, referred to al-Biruni as:

One of the greatest
scientists of Islam, and,
all considered, one of the
greatest of all times

(Sparavigna 2013)

Al-Biruni's important contribution in Geography, is known among others through his method of calculating the circumference of the earth, with trigonometric calculation techniques. (Sparavigna 2013)

Ibn Khaldun, also has a very high reputation among social science researchers. Kimble (1938) mentioned that Ibn Khaldun deserves to be called the discoverer of the scope and basic principles of Geography research (my be considered to have discovered the true scope and nature of geographical inquiry) (Kimble 1938, 180).
In his monumental work, Muqaddimah, Ibn Khaldun explained in detail the relationship between the geographical conditions of an area with the character of its population:
This is why we find knowledge, carpentry, buildings, clothing, food, and fruit, even animals and everything that lives in the middle of the region, have moderate and simple characteristics. Humans who inhabit the three regions mentioned above are also his body, skin color, manners, as well as his religion. Most of the holy revelations descended in these central regions. We have never heard of revelations revealed in the northern and southern regions. (Khaldun 2006, 89)

Because of his sharp analysis of geographical conditions and his characteristics with population characteristics, Preston E. James mentioned that Ibn Khaldun was the first scholar to pay particular attention to the relationship of humans with their environment. (Martin, Geoffrey J. and James 1981) 


\section{Geographical Conditions of Muslim}

\section{Countries.}

Muslim students need to be taught about the geographical conditions of Muslim countries where their brothers live.

Many Muslims in the world today are undereducated and socio-economically disadvantaged, topics such as world aid, the 'underdeveloped countries' and demographics are important for them. In addition, the question of national boundaries in several parts of the globe still remains a sensitive issue for many Muslims. Today, the great numbers of Muslims worldwide mean that Muslims are prominent in the study of world demographics.

On the contrary, in this aspect of content, it is necessary to analyze the material in the curriculum applied by the current government which is potentially not in harmony with Islamic values. Some material that has the potential to conflict or are not in harmony with the values and outlook on Islam include:

(1) In introduction to Geography, the purpose of learning Geography is only associated with materialistic motivation such as getting a job in the field of Geography
(2) Population dynamics, related to Malthussian theory of population and food growth Here it is explained that high population growth is considered a population problem.

(3) The diversity of Indonesian culture, related to efforts to preserve traditions that are contrary to Islamic values.

(4) Disaster mitigation and adaptation, which focuses on the physical causes of the disaster, as well as efforts to mitigate the impact of the disaster. Not discussed the causes of disasters which in Islam are also related to obedience and disobedience.

(5) Developed countries and developing countries, related to the concept and criteria of developed or underdeveloped a country which only considering materialistic factors such as income, education level ignoring the aspects of piety to God.

\section{c. Third Aspect: The Method of Geography Teaching}

Third, the teaching method takes its source from the guidance of the Qur'an, As and As Sunnah, and can be supported by ijtihad and the study of Islamic scholars who are 
competent in their fields, all of which are collected in the Islamic scientific realm, namely turats (Alim 2014, 93). Zarman (2016) explains that in an Islamic perspective, teaching science, not only discussing natural phenomena in the perspective of cause and effect, and how to make these natural phenomena useful for life. But also, more important than that, instilling religious values. Then, taking into account these goals, the method of teaching science will be very different from the current practice. That is, the teaching of science can no longer be separated from the teaching of revelation (al-Qur'an and asSunnah), given that science and revelation complement each other.(Zarman 2016)

As stated by Hashim, 1998 above, the method also includes providing learning experiences that are appropriate especially for moral and spiritual development by providing a balance between a studentcentered approach and a subject-centered approach.

\section{d. Fourth Aspect: The Evaluation}

Fourth, educational evaluation needs to pay attention to the achievement of the objectives of Islamic education, and not limited to aspects of knowledge, attitudes and skills but is empty of the achievement of ultimate educational goals.
Evaluation in the Geography curriculum should measure the achievement of learning objectives in the perspective of Islamic education. For example, measuring whether students when they see extraordinary natural phenomena, will relate it to the greatness of God. Another example, when looking at natural disasters, they not only pay attention to the physical causes of the disaster, but also relate it to obedience and disobedience.

\section{The Stages of Development of The} Geography Curriculum

The stages of developing the Geography curriculum are as follows:

1. The search for the realm of scientific Geography in the history of Islam and the position of Geography in Islamic civilization

2. Identification of materials that are important for Muslim students who need to be in the Geography curriculum

3. Analysis of the national curriculum, the classification of national curriculum materials that are aligned and potentially contradictory to Islamic values

4. Formulation of high school geography curriculum content based on Islamic values. 


\section{E. CONCLUSION}

Principles for the Compilation of Islamic Values Based Curriculum, among others: First, the objectives are aligned and are a translation of the objectives of Islamic education.

Second, the content of the material includes and corresponds to Islamic educational material including the history of Geography, great cotibution of Muslim scholars, and geographical conditions of Muslim countries. It also should be free from material content that are not aligned with Islamic values.

Third, the teaching method can no longer be separated from the teaching of revelation (al-Qur'an and as-Sunnah). It also should provide learning experiences that are appropriate especially for moral and spiritual development by providing a balance between a student-centered and a subject-centered approach.

Fourth, evaluation should pay attention to the achievement of the objectives of Islamic education, and not limited to aspects of knowledge, attitudes and skills but is empty of the achievement of true Islamic educational goals.

\section{REFERENCES}

Abdurrahmansyah. 2002. Sintesis Kreatif,

Pembaruan Kurikulum Pendidikan

Islam Ismail Raji Al Faruqi.

Jogjakarta: Global Pustaka Utama.

Al-Jazairy, Abu Bakar Jabir. 2001. Ilmu

Dan Ulama. Jakarta: Pustaka Azzam.

Al-Najjar, Zaghlul R. 1982. "Islamizing

The Teaching of Science: A Model in

Challenge and Response.” In Second

Conference on Islamization of

Knowledge, 146. Virginia:

International Institute of Islamic

Thought.

Al-Qannujy, Shidiq Hasan Khan. 1978.

Abjad Al-Ulum. Damascus: Wizarat

al-Tsaqafah wa al-Irsyad al-Qaumy.

Alim, Akhmad. 2014. Tafsir Pendidikan

Islam. Jakarta: AMP Press.

Bukhsh, S. Khuda. 1905. Contributions to

The History of Islamic Civilization.

Calcutta: Thacker Spink \& Co.

Handrianto, Budi. 2016. "Sains Islam:

Makna Filosofis Dan Model

Islamisasi.” In Islamic Science,

Paradigma, Fakta, Dan Agenda,

edited by Syamsuddin Arief, 59.

Jakarta: INSIST.

Khaldun, Ibn. 2006. Muqaddimah Ibn

Khaldun. Jakarta: Pustaka Firdaus. 
Kimble, George H T. 1938. Geography in The Middle Ages. New York: Russel \& Russel.

Langgulung, Hasan. 2001. "Islamisasi

Pendidikan Dari Perspektif

Metodologi.” Jurnal Pendidikan

Islam 9 (3): 25-26.

Mahmud. 2011. Metode Penelitian

Pendidikan. Bandung: Pustaka Setia.

Martin, Geoffrey J. and James, Preston E. 1981. All Possible Worlds, A History of Geographical Ideas. 3rd ed. New York: John Wiley \& Sons.

Nawi, Noor Hisham Md. 2012. "Islamisasi Kurikulum Pendidikan Islam Di Institusi Pendidikan Guru : Tribulasi Dan Cadangan.” In Kertas Kerja Persidangan Kebangsaan Pendidikan Islam, 4. Negeri Sembilan. http://umkeprints.umk.edu.my/id/epri $\mathrm{nt} / 623$.

Nordin, Sulaiman. 2000. Sains Menurut Perspektif Islam. Malaysia: Dewan Pustaka dan Bahasa kerjasama dengan PT Dwi Rama.

Salim, Abdullah Najib. 1999. Al-Ta'rif Bi Ba'dhi 'Ulum Al-Islam Al-Hanif. Kuwait: Wizarat al-Auqaf wa alSyu'un al-Islamiyyah.

Sparavigna, Amelia Carolina. 2013. "The
Science of Al-Biruni." The

International Journal of Sciences 2:

53.

Sukmadinata, Nana Syaodih. 2006. Metode Penelitian Pendidikan. Bandung: PT Remaja Rosdakarya.

Supraha, Wido. 2017. Pemikiran George Sarton Dan Panduan Islamisasi Sains. Depok: Yayasan Adab Insan Mulia.

Svd, Pushpa Anbu. 2010.

"RELATIONSHIP BETWEEN

Geography AND Islamic Thought." Interações: Cultura e Comunidade 5 (8): 45-62.

Tafsir, Ahmad. 2013. Ilmu Pendidikan Islami. Bandung: PT Remaja Rosdakarya.

Zarman, Wendi. 2016. "The Concept Of Nature In Islamic Science Teaching." In Proceedings of International Seminar on Mathematics, Science, and Computer Science Education, 3. Maryland: American Institute of Physics. https://doi.org/10.1063/1.4941196. 